\title{
Mycoplasma penetrans infection of Molt-3 lymphocytes induces changes in the lipid composition of host cells
}

\author{
Michael Salman, Zipi Borovsky and Shlomo Rottem
}

Department of Membrane and Ultrastructure Research, The Hebrew University-Hadassah Medical School, POB 12272, Jerusalem 91010, Israel
Author for correspondence: Shlomo Rottem. Tel: +972 2675 8148. Fax: +97226784010. e-mail: rottem@cc.huji.ac.il

The AIDS-associated Mycoplasma penetrans is capable of inducing its own uptake by non-phagocytic cells. The ability of $M$. penetrans to both adhere to and invade Molt-3 lymphocytes was markedly increased in the presence of polyethylene glycol 8000 (PEG). The effect of PEG was more pronounced in the more alkaline $\mathrm{pH}$ range, where the binding kinetics were much faster and almost unaffected by temperature $\left(4-37^{\circ} \mathrm{C}\right)$. Incubation of $\left[{ }^{14} \mathrm{C}\right]$ oleic-acidlabelled Molt- 3 cells with viable $M$. penetrans resulted in a substantial release of radioactive fatty acids, whereas treating the host cells with heat-inactivated mycoplasmas, isolated $M$. penetrans membrane preparations, or $M$. penetrans growth medium, had no effect. Total lipid analysis of Molt-3 lymphocytes infected by $M$. penetrans revealed an augmented level of the neutral lipid fraction that was associated with a decrease in the relative amounts of polar lipids, mainly a decrease in the amount of phosphatidylserine and diphosphatidylglycerol. Analysis of the neutral lipid fraction in the infected Molt-3 cells revealed a fivefold increase in the relative amount of diacylglycerol and a marked increase in the free fatty acid (FFA) fraction. The profile of the FFAs released was dominated by a relatively high concentration of the polyunsaturated fatty acid docosahexaenoic acid. The release of lipid intermediates suggests that the degradation of Molt-3 cell phospholipids induced by $M$. penetrans may initiate a signal transmission cascade in the host cell.

Keywords: mollicutes, Mycoplasma penetrans, phospholipase, membrane lipids, diacylglycerol

\section{INTRODUCTION}

Mycoplasmas (class Mollicutes) are simple selfreplicating prokaryotes widely distributed in nature as parasites and pathogens of animals, insects and plants. Almost all pathogenic mycoplasmas are bound to the cell surface of the host cells without being able to invade them (Razin \& Jacobs, 1992). However, Mycoplasma penetrans, recently isolated from the urogenital tract of AIDS patients, was shown to have invasive properties

\footnotetext{
Abbreviations: DAG, diacylglycerol; DHA, docosahexanoic acid; DPG, diphosphatidylglycerol; FFA, free fatty acid; PC, phosphatidylcholine; $P E$, phosphatidylethanolamine; PEG, polyethylene glycol 8000; PG, phosphatidylglycerol; PI, phosphatidylinositol; PKC, protein kinase C; $\mathrm{PLA}_{2 \text { r }}$ phospholipase $A_{2}$; PS, phosphatidylserine; SPM, sphyngomyelin; TG, triglycerides.
}

and an intracellular location in eukaryotic host cells (Lo, 1992; Lo et al., 1993; Andreev et al., 1995; Giron et al., 1996). M. penetrans also has a profound synergistic effect on HIV-1 cytopathogenic activities in infected human lymphocyte cultures (Lo, 1992) and it has been suggested that this organism plays a role in the pathogenesis of AIDS (Lo, 1992; Brenner et al., 1996).

Invasion is initiated by the binding of bacteria to the host-cell surface, followed by internalization (Falkow et al., 1992). We recently showed that in M. penetransinfected eukaryotic cells, protein kinase $\mathrm{C}$ (PKC) is translocated from the cytosol of the host cell to the plasma membrane (Borovsky et al., 1998), indicating the activation of the enzyme by an agonist (Neyrolles et al., 1996). The internalization of $M$. penetrans by nonphagocytic host cells is also dependent upon microfilament and/or microtubule functions, since the 
internalization is prevented by cytochalasin $\mathrm{D}$, which inhibits microfilament assembly (Andreev et al., 1995; Baseman et al., 1995; Giron et al., 1996), or by vinblastine, which disorganizes microtubules (Andreev et al., 1995; Borovsky et al., 1998). The activation of PKC and the active involvement of the host cytoskeleton suggests that $M$. penetrans generates 'uptake signals' which are transduced between the mycoplasma and the host cell across the host-cell membrane (Wick et al., 1991; Ruschkowsky et al., 1992; Giron et al., 1996). However, the nature of these signals and the mechanisms used to transduce them remain unknown.

We have recently shown that a $145 \mathrm{kDa}$ host-cell protein is tyrosine phosphorylated as a result of binding and/or invasion of a host cell by M. penetrans (Andreev et al., 1995 ) and the possibility that this protein represents a membrane-bound phospholipase has been suggested (Andreev et al., 1995; Borovsky et al., 1998).

The aim of this study was to investigate phospholipid degradation in Molt-3 lymphocytes infected by $M$. penetrans and to characterize the lipid intermediates released.

\section{METHODS}

Growth of mycoplasmas and tissue culture cells. $M$. penetrans was kindly provided by Dr S.-C. Lo (Armed Forces Institute of Pathology, Washington, DC, USA). The organisms were grown in modified Channock medium (Razin \& Rottem, 1976), supplemented with $10 \%(\mathrm{v} / \mathrm{v})$ heat-inactivated $\left(56^{\circ} \mathrm{C}\right.$ for $30 \mathrm{~min}$ ) horse serum (Biological Industries). Mycoplasma capricolum (strain California Kid) was grown in modified Edward medium (Razin \& Rottem, 1976), supplemented with $4 \%(v / v)$ heat-inactivated horse serum. For labelling of $M$. penetrans membrane lipids, $0.02 \mu \mathrm{Ci} \mathrm{m}$ m $^{-1}\left(740 \mathrm{~Bq} \mathrm{ml}^{-1}\right)$ $\left[9,10(\mathrm{n})-{ }^{3} \mathrm{H}\right]$ palmitic acid (Amersham), dissolved in ethanol, was added to the growth medium. For labelling cell proteins, $5 \mu \mathrm{Ci} \mathrm{m}^{-1}\left(185 \mathrm{kBq} \mathrm{ml}^{-1}\right) \mathrm{L}-\left[{ }^{35} \mathrm{~S}\right]$ methionine (Amersham) was added to the medium. The media were inoculated with $0 \cdot 1-2 \cdot 0 \%(\mathrm{v} / \mathrm{v})$ of a frozen inoculum and incubated at $37^{\circ} \mathrm{C}$ for 18-26 h. Growth was followed by measuring $\mathrm{OD}_{640}$, and by following $\mathrm{pH}$ changes in the growth media. Cells were harvested by centrifugation at $12000 \mathrm{~g}$ for $15 \mathrm{~min}$, washed once and suspended in A-buffer, consisting of $250 \mathrm{mM} \mathrm{NaCl}$, $10 \mathrm{mM} \mathrm{MgCl}_{2}$ and $10 \mathrm{mM}$ Tris/ $\mathrm{HCl}$ adjusted to $\mathrm{pH} 7.4$.

The human lymphocyte cell line $\mathrm{CD}^{+}$Molt- 3 was obtained from the American Type Culture Collection and maintained in RPMI 1640 medium, 20\% (v/v) foetal calf serum (FCS), penicillin $\left(100 \mu \mathrm{g} \mathrm{ml}^{-1}\right)$ and streptomycin $\left(100 \mu \mathrm{g} \mathrm{ml}^{-1}\right)$. All medium components were obtained from Biological Industries. Molt-3 cells were labelled with $\left[\mathrm{U}-{ }^{14} \mathrm{C}\right]$ palmitic acid (Amersham) $\left[928 \mathrm{Ci} \mathrm{mol}^{-1}\left(34 \mathrm{TBq} \mathrm{mol}^{-1}\right)\right]$, [U- ${ }^{14} \mathrm{C}$ ]oleic acid (Amersham) $\left[57 \cdot 4 \mathrm{Ci} \mathrm{mol}^{-1}\left(2 \cdot 1 \mathrm{TBq} \mathrm{mol}^{-1}\right)\right]$ or $\left[{ }^{32} \mathrm{P}\right]$ orthophosphate (Amersham) [3000 Ci mmol ${ }^{-1}\left(111 \mathrm{TBq}^{-1}\right)$ ] which were added to the growth medium $[0 \cdot 1-0 \cdot 2 \mu \mathrm{Ci} \mathrm{m})^{-1}$ $\left.\left(3 \cdot 7-7 \cdot 4 \mathrm{kBq} \mathrm{mol}^{-1}\right)\right] 24 \mathrm{~h}$ before harvesting. The fatty acids were dissolved in ethanol and the final concentration of ethanol in the medium did not exceed $0 \cdot 1 \%$. Cells were used prior to passage 40 and grown and assayed at $37{ }^{\circ} \mathrm{C}, 5 \% \mathrm{CO}_{2}$ and $90 \%$ humidity. Molt-3 cells were inoculated into the medium at a $1: 10$ ratio and grown to a density of $1-1 \cdot 2 \times 10^{6}$ cells $\mathrm{ml}^{-1}$ (about $72 \mathrm{~h}$ ). Viability of Molt- 3 cells was evaluated by the trypan blue exclusion.
Binding and invasion of $\boldsymbol{M}$. penetrans. To determine the number of bound $M$. penetrans cells, we used $M$. penetrans cells metabolically labelled by $\left[{ }^{3} \mathrm{H}\right]$ palmitate or $\left[{ }^{35} \mathrm{~S}\right]$ methionine. When cells are grown with radioactive palmitic acid, over $95 \%$ of the radioactivity is incorporated into the phospholipid fraction in two de novo synthesized phospholipids, phosphatidylglycerol (PG) and diphosphatidylgylcerol (DPG) (Salman \& Rottem, 1995). The radioactive mycoplasmas were added to Molt-3 cells in RPMI 1640 medium at a m.o.i. of 100 mycoplasmas per target cell and incubated for various periods of time at $4{ }^{\circ} \mathrm{C}$. The cell cultures were then washed twice with PBS to remove non-adherent bacteria and radioactivity was measured. Invasion of Molt-3 cells by $M$. penetrans was determined by the plating method (Andreev et al., 1995). Molt-3 cells were harvested at a density of $10^{6}$ cells $\mathrm{ml}^{-1}$, washed and resuspended in RPMI 1640 medium. Aliquots of $4 \mathrm{ml}$ were then inoculated with $M$. penetrans at a m.o.i. of 100 in the presence or absence of polyethylene glycol 8000 (PEG) and incubated for $2 \mathrm{~h}$ at $37^{\circ} \mathrm{C}$. The cultures were then washed twice, resuspended in RPMI 1640 containing $400 \mu \mathrm{g}$ gentamicin $\mathrm{ml}^{-1}$ (Biological Industries) and $0.01 \%$ Triton X-100, and incubated for $2 \mathrm{~h}$ at $37^{\circ} \mathrm{C}$. Following incubation, the lymphocytes were plated onto solid mycoplasma medium. Each mycoplasma colony obtained by this method represents an infected host cell rather than a single intracellular mycoplasma cell (Shaw \& Falkow, 1988).

Lipid analysis. Lipids were extracted from washed Molt-3 cells according to the method of Bligh \& Dyer (1959). Lipid phosphorus was determined after digestion of the sample in ethanolic magnesium nitrate (Rottem \& Markowitz, 1979). The lipids were separated by silicic acid column chromatography. The total lipid extract $(200 \mathrm{mg})$ in $2 \mathrm{ml}$ chloroform was loaded onto a silicic acid column that was eluted with 10 bed volumes of chloroform followed by 15 bed volumes of chloroform/methanol 1:1 (v/v). The fractions were evaporated to dryness under a stream of nitrogen, redissolved in chloroform and kept at $-20^{\circ} \mathrm{C}$. The neutral lipid fraction, eluted from the column with chloroform, was separated by chromatography on silica gel G plates (Sigma) using the twostep development system (Rottem, 1980). The plates were first developed in benzene/diethyl ether/ethanol/acetic acid $(50: 40: 2: 0 \cdot 2$, by vol. $)$, then dried and developed in the same direction in hexane/diethyl ether (94:6, v/v), (Rottem, 1983). The polar lipid fractions eluted from the column with chloroform/methanol were separated on silica gel HR plates and developed at $4{ }^{\circ} \mathrm{C}$ in chloroform/methanol/water $(65: 25: 4$, by vol.). Two-dimensional TLC of polar lipids was performed on silica gel HR plates: the plates were developed in the first direction in chloroform $/$ methanol $/ 28 \%$ ammonia $(65: 25: 4$, by vol.), and in the second direction in chloroform/ methanol/water $(65: 25: 4$, by vol.). Polar lipid standards were run in both directions on the right sides of the TLC plates. Lipid spots were detected by iodine vapour, phospholipid spots by molybdate spray reagent, glycolipids by anthrone reagent and aminophospholipids by ninhydrin reagent (Rottem, 1983).

To quantify the phosphorus in the phospholipid spots resolved by TLC, the spots were scraped off the plate and digested with $0.2 \mathrm{ml}$ ethanolic magnesium nitrate solution in the presence of silica gel. To measure the radioactivity of the lipid spots, the spots were scraped off the plate into scintillation vials containing $5 \mathrm{ml}$ Lumax scintillation liquor and radioactivity was measured in a Packard Tri-Carb scintillation spectrometer and expressed as d.p.m. Alternatively, the TLC plates were exposed to imaging plates (Fuji Photo Film) for $6 \mathrm{~h}$ and then processed, using the Fujix BAS 1000 (Fuji) radiation 
image analysis system and the radioactivity in each lipid spot was determined.

Fatty acid analysis. Fatty acid methyl esters were prepared by heating the lipid samples in $14 \%$ boron trifluoride in methanol at $72{ }^{\circ} \mathrm{C}$ for $15 \mathrm{~min}$. The resulting methyl esters were extracted twice with hexane and subjected to GLC in a Trakor 540 gas-liquid chromatograph equipped with a polar column $(100 \times 0.2 \mathrm{~cm}$, packed with $10 \%$ SP 2330 on $100 / 120$ mesh Chromosorb W, Supelco). Fatty acids were identified by their retention times relative to those obtained with standard mixtures of fatty acid methyl esters (Rottem, 1983). Alternatively, fatty acid methyl esters were separated on silica gel G plates impregnated with $15 \%(\mathrm{w} / \mathrm{v}) \mathrm{AgNO}_{3}$ for separation of fatty acids with different degrees of unsaturation. For separation of fatty acids with $0-2$ double bonds, a mixture of hexane/diethyl ether $(9: 1, \mathrm{v} / \mathrm{v})$ was used, and for separation of fatty acids with 3-6 double bonds, a mixture of hexane/ diethyl ether (2:3, v/v) was used (Christie, 1989).

\section{RESULTS}

\section{Effect of PEG on binding and internalization of $M$. penetrans}

It has been previously shown that $M$. penetrans adheres to cultured human cells in a time-dependent manner but the binding rates observed were very slow, with maximal binding obtained after $6-12 \mathrm{~h}$ incubation (Giron et al., 1996). To check the possibility that the slow binding rate was due to a water layer adjacent to the surface polysaccharide, recently described in $M$. penetrans (Neyrolles et al., 1996), we used PEG to perturb surface water structure and allow better contact between cells (Lucy \& Ahkong, 1989). Fig. 1 shows that when ${ }^{3} \mathrm{H}-$ labelled M. penetrans was incubated with Molt-3 cells for $2 \mathrm{~h}$ at $37^{\circ} \mathrm{C}$ the level of adherence was markedly affected by PEG. The process was concentration de-

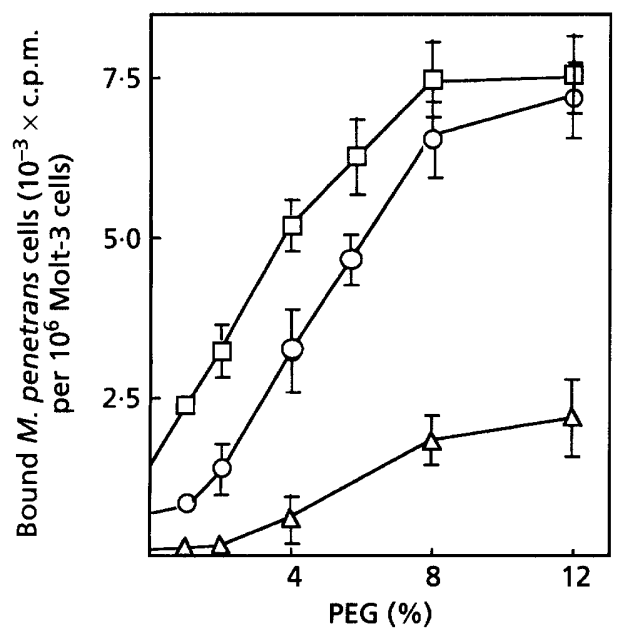

Fig. 1. Effect of PEG on the binding of ${ }^{3} \mathrm{H}$-labelled $M$. penetrans to Molt-3 cells at various pHs. Labelled $M$. penetrans were incubated with Molt-3 cells $(m .0 . i .=100)$ and various PEG concentrations for $2 \mathrm{~h}$ at $4{ }^{\circ} \mathrm{C}$. Binding was carried out at $\mathrm{pH} 5.0$ $(\triangle), \mathrm{pH} 7.0(\square)$ or $\mathrm{pH} 9.0(\bigcirc)$. Data represent means \pm SD from three independent experiments.

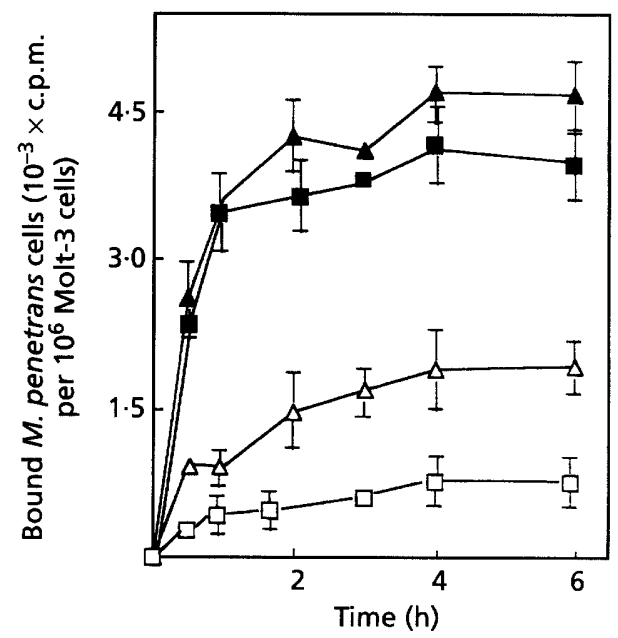

Fig. 2. Effect of temperature and PEG on the binding of ${ }^{3} \mathrm{H}$ labelled $M$. penetrans to Molt-3 cells. Labelled $M$. penetrans were incubated with Molt-3 cells at a m.o.i. $=100$ for various periods of time with (filled symbols) or without (open symbols) $8 \%$ PEG. Binding was assayed at $4{ }^{\circ} \mathrm{C}(\square, \square)$ or $37^{\circ} \mathrm{C}(\triangle, \Delta)$. Results presented are means \pm SD from three independent experiments.

pendent, with marked enhancement of binding at $8-12 \%$ PEG. The effect of PEG was most pronounced at $\mathrm{pH} 7 \cdot 0$ and $9 \cdot 0$, and less pronounced at $\mathrm{pH} 5 \cdot 0$. Fig. 2 shows the profile of binding of M. penetrans to Molt-3 cells in the presence and absence of PEG over time. In the presence of $8 \%$ PEG, the binding kinetics were much faster and almost unaffected by temperature $\left(4-37^{\circ} \mathrm{C}\right)$, whereas in the absence of PEG, the levels of binding at $37^{\circ} \mathrm{C}$ were higher than those seen at $4{ }^{\circ} \mathrm{C}$. PEG also had a marked effect on the internalization of $M$. penetrans by Molt-3 cells (Table 1). Internalization was studied by the plating method, where gentamicin resistance in the presence of $0.01 \%$ Triton X-100 is used to determine intracellular mycoplasmas (Andreev et al., 1995). In the presence of $8 \%$ PEG the number of Molt-3 cells invaded by $M$. penetrans was markedly higher than the number of invaded cells in the absence of PEG (Table 1). Therefore, PEG $(8 \% \mathrm{v} / \mathrm{v})$ was added to all subsequent experiments. Neither binding nor internalization was affected by inhibiting protein synthesis in $M$. penetrans by pretreatment with chloramphenicol $\left(50-100 \mu \mathrm{g} \mathrm{ml}^{-1}\right)$ for $2 \mathrm{~h}$ at $37^{\circ} \mathrm{C}$. However, internalization was almost completely inhibited $(93 \pm 5 \%$ inhibition; mean $\pm \mathrm{SD}, n$ 3) by cytochalasin $\mathrm{D}\left(\overline{5} \mu \mathrm{g} \mathrm{ml} l^{-1}\right)$.

\section{Effect of $M$. penetrans on the release of free fatty acids from Molt-3 cells}

Treatment of $\left[{ }^{14} \mathrm{C}\right]$ oleic-acid-labelled Molt- 3 cells with pancreatic phospholipase $\mathrm{A}_{2}\left(\mathrm{PLA}_{2}\right)$ resulted in the release of $86 \pm 6 \%$ (mean $\pm S D, n=3$ ) of the incorporated radioactivity as free fatty acids (FFA) compared with a release of about $21 \%$ obtained when $\left[{ }^{14} \mathrm{C}\right]$ palmitic acid-labelled Molt-3 cells were treated with PLA $\mathrm{P}_{2}$, suggesting that most of the oleic acid added 
Table 1. Effect of PEG on binding to and invasion of Molt-3 cells by M. penetrans

Molt- 3 cells were infected with palmitic-acid-labelled $M$. penetrans at $4{ }^{\circ} \mathrm{C}$ or $37^{\circ} \mathrm{C}$ for $2 \mathrm{~h}$. Binding was calculated from the residual radioactivity associated with the Molt- 3 cells incubated with the mycoplasmas at $4{ }^{\circ} \mathrm{C}$. The data presented are means \pm SD of three different experiments. PFA, paraformaldehyde.

\begin{tabular}{|cccc|}
\hline Condition & $\begin{array}{c}\text { Molt-3 cells } \\
\text { treated with }\end{array}$ & $\begin{array}{c}\text { Bound } \\
\text { M. penetrans } \\
\text { (c.p.m. per 10 } \\
\text { Molt-3 cells })\end{array}$ & $\begin{array}{c}\text { Internalized } \\
\text { M. penetrans } \\
\text { (c.f.u. per 10 } \\
\text { Molt-3 cells })\end{array}$ \\
\hline Without PEG & None & $1390 \pm 400$ & $5500 \pm 2000$ \\
& PFA (4\%) & $1460 \pm 450$ & $2000 \pm 1000$ \\
With PEG (8\%) & None & $7460 \pm 680$ & $17000 \pm 2000$ \\
& PFA (4\%) & $6800 \pm 720$ & $2500 \pm 1000$ \\
\hline
\end{tabular}

Table 2. Effect of mycoplasmas on the release of FFA from Molt-3 cells

$\left[{ }^{14} \mathrm{C}\right]$ Oleate-labelled Molt -3 cells were incubated for $18 \mathrm{~h}$ with various stimulants. The concentration of stimulants other than viable mycoplasmas was standardized to m.o.i. $=100$. The data presented are means \pm SD of three different experiments.

\begin{tabular}{|lcc|}
\hline Molt-3 cells treated with & $\begin{array}{c}\text { Radioactivity } \\
\text { in FFA } \\
\text { fraction }(\%)\end{array}$ & $\begin{array}{c}\text { Viability of } \\
\text { Molt-3 } \\
\text { cells }(\%)\end{array}$ \\
\hline None & $<0 \cdot 2$ & $90 \pm 5$ \\
M. penetrans cells & $8 \cdot 3 \pm 2 \cdot 6$ & $70 \pm 8$ \\
Heat-inactivated cells & $<0 \cdot 2$ & $83 \pm 10$ \\
Isolated membranes & $<0 \cdot 2$ & $86 \pm 7$ \\
Soluble fraction & $<0 \cdot 2$ & $89 \pm 9$ \\
Lipid extract & $<0 \cdot 2$ & $94 \pm 4$ \\
M. capricolum cells & $<0 \cdot 2$ & $64 \pm 8$ \\
Medium* & $<0 \cdot 2$ & $92 \pm 5$ \\
\hline
\end{tabular}

* The medium was obtained after harvesting $M$. penetrans cells and was added to the RPMI medium to a final concentration of $10 \%$.

to the medium was incorporated as an unsaturated fatty acyl into position 2 of the glycerol. To verify this observation, total lipids of palmitate- and oleatelabelled Molt-3 cells were transmethylated, and the fatty acid methyl esters were separated by argentation TLC, according to the number of double bonds (Christie, 1990). Autoradiography of the plates revealed that following labelling with oleic acid, most of the radioactivity (over $90 \%$ ) was recovered in the monounsaturated band, suggesting that the majority of the oleic acid incorporated from the medium was not metabolized. Only $2.8 \%$ of the radioactivity was detected in the saturated fatty acid band, and $5.4 \%$ in the polyunsaturated fatty acid band. When the cells were labelled with palmitic acid, about $75 \%$ of the total radioactivity was recovered in the saturated fatty acid band, whereas $15 \%$ was detected in the monounsaturated fraction. $\left[{ }^{14} \mathrm{C}\right]$ Oleic-acid-labelled Molt-3 cells were, therefore, used in subsequent experiments. Incubation of $M$. penetrans with $\left[{ }^{14} \mathrm{C}\right]$ oleic-acid-labelled Molt-3 cells at a m.o.i. of 100 resulted in a substantial release of radioactive FFA (Table 2), compared with the extremely low level (approx. $0.2 \%$ ) of FFA in a control of untreated Molt- 3 cells. FFA release was observed only with viable $M$. penetrans, whereas heat-inactivated mycoplasmas $\left(65^{\circ} \mathrm{C}, 10 \mathrm{~min}\right)$, isolated $M$. penetrans membrane preparations, and the soluble fraction derived from $M$. penetrans after disrupting the mycoplasmas by ultrasonic treatment, had no effect. Table 2 also shows that the viability of Molt-3 cells incubated with $M$. penetrans was moderately affected (a decrease of $20-30 \%$ ). To determine whether the fatty acid release was due to the death of host cells rather than to the invasion process, a control experiment was performed with the non-invasive $M$. capricolum that, under identical experimental conditions, was found to induce a more pronounced cell death of Molt-3. However, this organism did not cause appreciable FFA release (Table 2). FFA release was also observed when native Molt-3 cells were infected with $M$. penetrans in the presence of chloramphenicol but not after $M$. penetrans infection of cytochalasin D-treated Molt-3 cells (Table 3). The decrease in viability of cytochalasin D-treated cells incubated with $M$. penetrans was identical to that of infected native Molt-3 cells (Table 3 ). As can be seen in Fig. 3, released FFA were first detected after $4 \mathrm{~h}$ incubation, with maximal accumulation observed at $18 \mathrm{~h}$ incubation.

\section{Changes in the polar and neutral lipid composition of Molt-3 cells incubated with $M$. penetrans}

The polar lipid composition of Molt-3 cells incubated with or without $M$. penetrans was analysed by twodimensional TLC of [ ${ }^{32}$ P] orthophosphate-labelled Molt3 cells followed by autoradiography. A pronounced decrease in the amount of phosphatidylserine (PS) and a reduced concentration of DPG were detected in cells 
Table 3. Release of FFA from Molt-3 cells incubated with $M$. penetrans

$\left[{ }^{14} \mathrm{C}\right]$ Oleate-labelled Molt-3 cells were incubated for $12 \mathrm{~h}$ with native or with chloramphenicol $\left(100 \mu \mathrm{g} \mathrm{ml}^{-1}\right)$ treated $M$. penetrans at a m.o.i. of 100 . The data presented are means \pm SD of three different experiments.

\begin{tabular}{|lccc|}
\hline Molt-3 cells treated with & $\begin{array}{c}\text { M. penetrans } \\
\text { preparation }\end{array}$ & $\begin{array}{c}\text { Radioactivity } \\
\text { in FFA } \\
\text { fraction (\%) }\end{array}$ & $\begin{array}{c}\text { Viability of } \\
\text { Molt-3 cells (\%) }\end{array}$ \\
\hline Paraformaldehyde $(4 \%)$ & Native & $<0 \cdot 2$ & 0 \\
Cytochalasin D & Native & $<0 \cdot 2$ & $80 \pm 5 \cdot 0$ \\
Quinacrine $(100 \mu \mathrm{M})$ & Native & $<0 \cdot 2$ & $76 \pm 5 \cdot 0$ \\
Mepacrine $(100 \mu \mathrm{M})$ & Native & $<0 \cdot 2$ & $80 \pm 5 \cdot 0$ \\
None & Native & $7 \cdot 8 \pm 2 \cdot 5$ & $75 \pm 5 \cdot 0$ \\
None & Chloramphenicol & $6 \cdot 6 \pm 2 \cdot 0$ & $80 \pm 5 \cdot 0$ \\
& treated & & \\
\hline
\end{tabular}

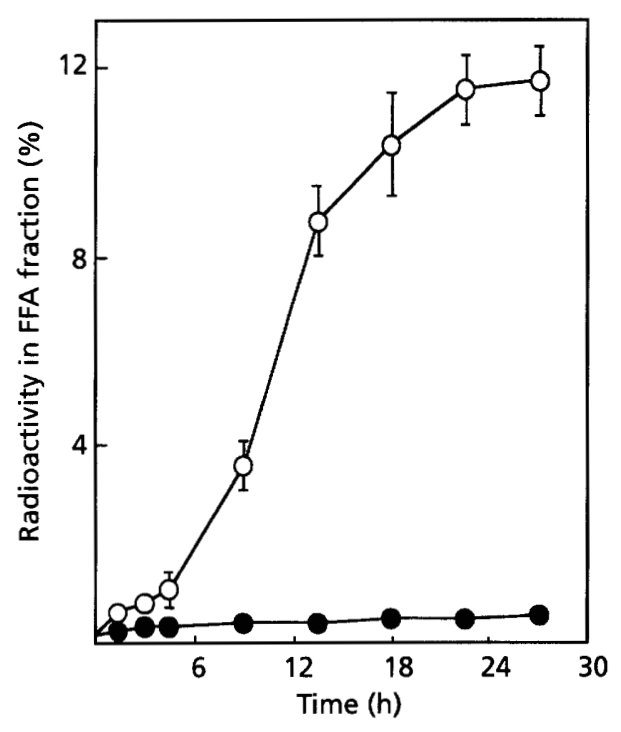

Fig. 3. Kinetics of FFA release. Molt-3 cells were incubated for the designated periods of time with $(O)$ or without $(0) M$. penetrans at a m.o.i. of 100 . Lipids were extracted and the radioactivity in the FFA fraction was determined as described in Methods. Results are expressed as the mean radioactivity in the FFA fraction in triplicate experiments $\pm S D$.

incubated with $M$. penetrans (Table 4). As the total amount of polar lipids in the cells incubated with $M$. penetrans was lower than that in control cells incubated without the mycoplasma (a polar to neutral lipid ratio of 2.5 , compared with 4.9 in the control cells), an increase in the relative amounts of phosphatidylcholine (PC) and phosphatidylethanolamine (PE) was also recorded.

Analysis of the neutral lipid fraction of cells is presented in Table 5. A fivefold increase in the relative amount of diacylglycerol (DAG) and a marked increase in FFA were observed in Molt-3 cells infected with $M$. penetrans. The increase in the total neutral lipids was associated with a decrease in the relative amounts of the polar lipids.

\section{Identification of the fatty acids released from the Molt-3 lipids after interaction with $M$. penetrans}

The fatty acid composition of the total lipid fraction of Molt- 3 cells and of the FFA fraction released from Molt3 cells upon incubation with $M$. penetrans is shown in Table 6. The main saturated fatty acids in the total lipid fraction were palmitic $(16: 0)$, stearic $(18: 0)$ and myristic acid $(14: 0)$; the unsaturated fatty acids consisted primarily of oleic $(18: 1)$ palmitoleic $(16: 1)$, arachidonic $(20: 4)$ and docosahexanoic acid (DHA, 22:6). The fatty acid profile of the FFA fraction obtained from Molt-3 cells incubated with $M$. penetrans revealed a higher level of unsaturated fatty acids, with an unsaturated to saturated fatty acid ratio of $1 \cdot 21$, compared with a ratio of 0.92 in the total lipid fraction of the infected cells and 0.75 in the total lipid fraction of uninfected control cells. The fatty acid profile of the FFA fraction was dominated by high concentrations of the polyunsaturated fatty acid DHA. The levels of DHA were always three- to fourfold higher than those of the arachidonic acid released. The $\mathrm{PLA}_{2}$ inhibitors quinacrine and mepacrine did not affect the release of fatty acids (Table 3 ).

\section{DISCUSSION}

The prominent effect of $M$. penetrans in enhancing HIV1 cytopathogenicity of human lymphocyte cultures (Lo, 1992) prompted us to investigate the effects, at the molecular level, of $M$. penetrans on a human $\mathrm{CD}^{+}$ lymphocyte cell line. We found that PEG markedly increased the ability of the mycoplasma to both adhere to and invade Molt-3 lymphocytes, as judged by the resistance to extracellular gentamicin (Andreev et al., 1995). Many investigators have recognized the ability of PEG to alter the physical state of bulk water adjacent to the cell membrane surface (Lucy \& Ahkong, 1989; Nir et al., 1986). At high concentrations ( $\geqslant 20 \%$ ) PEG was found to destabilize the lipid backbone (Lucy \& Ahkong, 1989). We observed enhanced binding of $M$. penetrans to Molt-3 cells at a relatively low PEG concentration $(8 \%)$ that causes virtually no change in 
Table 4. Phospholipid composition of ${ }^{32}$ P-labelled Molt-3 cells incubated with or without M. penetrans

Values are means $\pm S D$ of three different experiments.

\begin{tabular}{|c|c|c|}
\hline \multirow[t]{2}{*}{ Phospholipid } & \multicolumn{2}{|c|}{$\begin{array}{c}\text { Radioactivity }(\%) \text { in phospholipids } \\
\text { extracted from Molt-3 } \\
\text { cells incubated }\end{array}$} \\
\hline & $\begin{array}{l}\text { Without } \\
\text { M. penetrans }\end{array}$ & $\begin{array}{c}\text { With } \\
\text { M. penetrans }\end{array}$ \\
\hline Sphingomyelin & $1 \cdot 2 \pm 0 \cdot 2$ & $1 \cdot 5 \pm 0 \cdot 2$ \\
\hline Phosphatidylserine & $12 \cdot 3 \pm 1 \cdot 6$ & $3 \cdot 2 \pm 0 \cdot 6$ \\
\hline Phosphatidic acid & $0 \cdot 3 \pm 0 \cdot 1$ & $<\overline{0} \cdot 1$ \\
\hline Phosphatidylcholine & $48 \cdot 8 \pm 4 \cdot 0$ & $53 \cdot 9 \pm 4 \cdot 5$ \\
\hline Phosphatidylethanolamine & $29 \cdot 1 \pm 3 \cdot 0$ & $31 \cdot 7 \pm 3 \cdot 0$ \\
\hline Diphosphatidylglycerol & $6 \cdot 3 \pm 0 \cdot 8$ & $2 \cdot 8 \pm 0 \cdot 5$ \\
\hline Phosphatidylglycerol & $<\overline{0} \cdot 1$ & $<\overline{0} \cdot 1$ \\
\hline
\end{tabular}

Table 5. Neutral lipid composition of $\left[{ }^{14} \mathrm{C}\right]$ oleate-labelled Molt-3 cells incubated with or without $M$. penetrans

$\left[{ }^{14} \mathrm{C}\right]$ Oleate-labelled Molt-3 cells were incubated with or without M. penetrans $(\mathrm{m} .0 . \mathrm{i} .=100)$ for $18 \mathrm{~h}$. The values presented are means \pm SD of three different experiments.

\begin{tabular}{|c|c|c|c|}
\hline \multirow[t]{3}{*}{ Neutral lipids } & \multicolumn{3}{|c|}{ Radioactivity in neutral lipids (\%) } \\
\hline & \multicolumn{2}{|c|}{$\begin{array}{c}\text { Molt-3 incubated without } \\
\text { M. penetrans }\end{array}$} & \multirow{2}{*}{$\begin{array}{l}\text { Molt-3 incubated with } \\
\text { M. penetrans } \\
(18 \mathrm{~h})\end{array}$} \\
\hline & $(\mathbf{0} \mathrm{h})$ & $(18 \mathrm{~h})$ & \\
\hline Monoglycerides & $<0 \cdot 1$ & $<0.1$ & $<0 \cdot 1$ \\
\hline Diglycerides & $0 \cdot 2 \pm 0 \cdot 1$ & $0 \cdot 3 \pm 0 \cdot 1$ & $1 \cdot 1 \pm 0 \cdot 3$ \\
\hline Triglycerides & $15 \cdot 0 \pm 4 \cdot 0$ & $15 \cdot 5 \pm 3 \cdot 2$ & $18 \cdot 7 \pm 2 \cdot 5$ \\
\hline Free fatty acids & $0 \cdot 2 \pm 0 \cdot 1$ & $1 \cdot 3 \pm 1 \cdot 0$ & $8 \cdot 0 \pm 2 \cdot 0$ \\
\hline Total neutral lipids & $15 \cdot 5 \pm 4 \cdot 2$ & $17 \cdot 2 \pm 4 \cdot 3$ & $27 \cdot 9 \pm 4 \cdot 8$ \\
\hline
\end{tabular}

Table 6. Fatty acid composition of the total lipid and FFA fractions released from Molt-3 cells infected with $M$. penetrans

The fatty acid methyl esters were identified on the basis of retention time compared with that of commercial standards. The data shown are the means of two experiments.

\begin{tabular}{|c|c|c|c|c|c|c|c|c|c|c|c|c|c|c|}
\hline \multirow{2}{*}{$\begin{array}{l}\text { Molt-3 cell } \\
\text { preparation }\end{array}$} & \multirow{2}{*}{$\begin{array}{l}\text { Lipid } \\
\text { fraction* }\end{array}$} & \multicolumn{13}{|c|}{ Fatty acid $\dagger(\mathrm{mol} \%)$} \\
\hline & & $14: 0$ & $16: 0$ & $16: 1$ & $18: 0$ & $18: 1$ & $18: 2$ & $18: 3$ & $20: 2$ & $20: 3$ & $20: 4$ & $20: 5$ & $22: 5$ & $22: 6$ \\
\hline \multirow{3}{*}{$\begin{array}{l}\text { Uninfected } \\
\text { Infected }\end{array}$} & $\mathrm{TL}$ & $13 \cdot 0$ & $25 \cdot 5$ & $3 \cdot 8$ & $19 \cdot 5$ & $27 \cdot 0$ & $1 \cdot 0$ & $1 \cdot 5$ & $<0.5$ & $<0.5$ & $6 \cdot 0$ & 1.5 & $<0.5$ & 2.5 \\
\hline & TL & $12 \cdot 5$ & $23 \cdot 1$ & $5 \cdot 1$ & $16 \cdot 1$ & $26 \cdot 0$ & $1 \cdot 2$ & $1 \cdot 2$ & 0.6 & 0.8 & $5 \cdot 3$ & 0.8 & 0.8 & 5.9 \\
\hline & FFA & $10 \cdot 5$ & $20 \cdot 3$ & $7 \cdot 5$ & $14 \cdot 6$ & $27 \cdot 5$ & - & - & - & - & $3 \cdot 2$ & - & - & $16 \cdot 7$ \\
\hline
\end{tabular}

* TL, total lipids; FFA, free fatty acids.

† The first number indicates the number of carbon atoms and the second number, the number of double bonds. 
the freedom of motion of membrane phospholipids (M. Salman \& S. Rottem, unpublished data). Hence, it is likely that the perturbations in the surface water structure induced by PEG sufficed to enhance the binding of the mycoplasma. Uptake of $M$. penetrans by Molt-3 cells was not dependent on protein synthesis, as pretreatment of $M$. penetrans with chloramphenicol affected neither their binding nor their internalization by the host cells.

Infection of Molt-3 lymphocytes by $M$. penetrans resulted in a substantial release of fatty acids, suggesting changes in the lipid turnover of the host cells. By contrast, very low concentrations of fatty acids were released when Molt-3 cells were incubated with $M$. capricolum, although the latter exhibited a higher cytotoxicity toward lymphocytes than the $M$. penetrans preparation. Furthermore, fatty acid release was not observed when heat-inactivated intact $M$. penetrans cells or isolated $M$. penetrans membranes were used or after $M$. penetrans infection of cytochalasin D-treated Molt -3 cells. These observations suggest that fatty acids are being released due to the invasion of Molt- 3 cells by $M$. penetrans rather than to Molt-3 cell death or to toxic effects of $M$. penetrans. The finding that accumulation of fatty acids was detected only after $6 \mathrm{~h}$ of incubation, and reached a high level only at $18 \mathrm{~h}$, suggests that the release is a slow process. Our fatty acid analysis revealed that both saturated and unsaturated free fatty acids were released. The unsaturated ones were predominantly very long polyunsaturated DHA $(22: 6)$, which constituted about $17 \%$ of the total FFA released, although in the total lipid fraction, DHA constitutes some $6 \%$. DHA is widely present in human tissues (Katan et al., 1997) but scant information is available on its physiological role.

The findings that the major neutral lipid fraction present in Molt-3 cells infected by M. penetrans was the FFA fraction that contained almost equimolar amounts of saturated and unsaturated fatty acids suggests that they are formed by the activity of lipases and/or non-specific esterases rather than by $\mathrm{PLA}_{2}$, which liberates principally unsaturated FFA (Rottem, 1980). This notion was further supported by our inability to prevent FFA release by $\mathrm{PLA}_{2}$ inhibitors (mepacrine or quinacrine). It is also unlikely that phospholipase $\mathrm{A}_{1}$, recently characterized in M. penetrans membranes (Salman \& Rottem, 1995), is responsible for the fatty acid release because it attacks the sn-1 position of phospholipids, where most of the fatty acids are saturated ones. It is possible that in our experiments the source of the released unsaturated fatty acids was the DAG accumulated as a result of phospholipase C activity (Shibata et al., 1995), which could have been hydrolysed by the sequential action of 1-diacylglycerol lipase and 2-monoacylglycerol lipase (Balsinde et al., 1991).

Are other lipid intermediates rather than FFA being released and what is the source of the FFA released in the infected lymphocytes? Analysis of the neutral lipid fraction from Molt-3 cells incubated with $M$. penetrans revealed an increase in the amount of DAG, a wellestablished second messenger released apparently due to the activation of phospholipase C (Liscowitch, 1992). The finding of a pronounced reduction in the amount of phosphatidylserine (PS) and DPG suggests that these lipids are the major phospholipids hydrolysed. We recently showed that the interaction of $M$. penetrans with HeLa cells leads to the activation of PKC, which takes part in cellular responses to various agonists (Borovsky et al., 1998). A similar activation has been observed when Molt-3 cells were infected with $M$. penetrans ( $\mathrm{M}$. Tarshis \& S. Rottem, unpublished data). PKC activation can be triggered by an increased concentration of membrane DAG, resulting from agonist-induced hydrolysis of inositol phospholipids by phospholipase C (Nishizuka, 1992; Wick et al., 1991). The DAG thus generated is frequently followed by a more sustained increase in DAG, due to the hydrolysis of other membrane phospholipids by phospholipase D in an agonist-dependent manner, culminating in the formation of phosphatidic acid that is then converted to DAG by a phosphatidic acid phosphomonoesterase (Nishizuka, 1992). Several cis-unsaturated fatty acids, including oleic, linoleic, linolenic, arachidonic and docosahexanoic acid, also enhance the DAG-dependent activation of PKC, allowing PKC to exhibit nearly full activity (Liscowitch, 1992; Nishizuka, 1992). In our study, the level of DAG produced in $M$. penetransstimulated Molt- 3 cells was low, but almost five times higher than that in unstimulated control cells. The low DAG level may be accounted for by the high levels of DAG lipase and non-specific esterases present in $T$ lymphocytes (Nishizuka, 1992).

In conclusion, we have provided evidence that infection of lymphocytes by $M$. penetrans is associated with the release of lipid intermediates that may function in signal transduction across the host-cell membrane. The role of these signals in the penetration, survival and proliferation of the mycoplasma within the lymphocytes, as well as the involvement of the lipid intermediates in the pathobiological alterations taking place in the host cells, merit further investigation.

\section{ACKNOWLEDGEMENTS}

We would like to thank J. Andreev and A. Katzenel for their invaluable assistance. This study was supported by a grant from the Israel Ministry of Health.

\section{REFERENCES}

Andreev, J., Borovsky, Z., Rosenshine, I. \& Rottem, S. (1995). Invasion of $\mathrm{HeLa}$ cells by Mycoplasma penetrans and the induction of tyrosine phosphorylation of a $145 \mathrm{kDa}$ host cell protein. FEMS Lett 132, 189-194.

Balsinde, J., Diez, E. \& Mollinedo, F. (1991). Arachidonic acid release from diacylglycerol in human neutrophils. J Biol Chem 266, 15638-15643.

Baseman, J. B., Lange, M., Criscimagna, N. L., Giron, J. A. \& Thomas, C. A. (1995). Interplay between mycoplasmas and host target cells. Microb Pathog 19, 105-116. 
Bligh, E. G. \& Dyer, W. J. (1959). A rapid method of total lipid extraction and purification. Can J Biochem Physiol 37, 911-917.

Borovsky, Z., Tharshis, M., Zhang, P. \& Rottem, S. (1998). Protein kinase $\mathrm{C}$ activation and vacuolation in HeLa cells invaded by Mycoplasma penetrans. J Med Microbiol 47, 915-922.

Brenner, C., Neyrolles, O. \& Blanchard, A. (1996). Mycoplasmas and HIV infection: from epidemiology to their interaction with immune cells. Front Biosci 1, e42-54.

Christie, W. W. (1989). Gas Chromatography and Lipids. Ayr: The Oily Press.

Falkow, S., Isberg, R. R. \& Portnoy, D. A. (1992). The interaction of bacteria with mammalian cells. Annu Rev Cell Biol 8, 333-363.

Giron, J. A., Lange, M. \& Baseman, J. B. (1996). Adherence, fibronectin binding, and induction of cytoskeleton reorganization in cultural human cells by Mycoplasma penetrans. Infect Immun 64, 197-208.

Katan, M. B., Deslypere, J. P., van Birgelen, A. P., Penders, M. \& Zegwaard, M. (1997). Kinetics of the incorporation of dietary fatty acids into serum cholesteryl esters, erythrocyte membranes, and adipose tissue: an 18-month controlled study. J Lipid Res 38, 2012-2022.

Liscowitch, M. (1992). Crosstalk among multiple signal-activated phospholipases. Trends Biochem Sci 17, 393-398.

Lo, S.-C. (1992). Mycoplasma and AIDS. In Mycoplasmas: Molecular Biology and Pathogenesis, pp. 525-548. Edited by J. Maniloff, R. N. McElhaney, L. R. Finch \& J. B. Baseman. Washington, DC: American Society for Microbiology.

Lo, S.-C., Hayes, M. M., Kotani, H., Pierce, P. F., Wear, D. J., Newton, P. B., Tully, J. G. \& Shih, J. W. (1993). Adhesion onto and invasion into mammalian cells by Mycoplasma penetrans: a newly isolated mycoplasma from patients with AIDS. Mod Pathol 6, 276-280.

Lucy, J. A. \& Ahkong, Q. F. (1989). Membrane fusion. Fusogenic agents and osmotic forces. Subcell Biochem 14, 189-228.

Neyrolles, O., Brenner, C., Prevost, M.-C., Fontaine, T., Montagnier, L. \& Blanchard, A. (1996). Isolation and characterization of a novel capsule-like material from Mycoplasma penetrans. IOM Lett 4, 366-367.
Nir, S., Klappe, K. \& Hoekstra, D. (1986). Mass action analysis of kinetics and extent of fusion between Sendai virus and phospholipid vesicles. Biochemistry 25, 8261-8266.

Nishizuka, Y. (1992). Intracellular signaling by hydrolysis of phospholipids and activation of protein kinase C. Science 228, 607-614.

Razin, S. \& Jacobs, E. (1992). Mycoplasma adhesion. J Gen Microbiol 138, 407-422.

Razin, S. \& Rottem, S. (1976). Techniques for the manipulation of mycoplasma membranes. In Biochemical Methods in Membrane Studies, pp. 3-26. Edited by A. H. Maddy. London: Chapman \& Hall.

Rottem, S. (1980). Membrane lipids of mycoplasma. Biochim Biophys Acta 604, 65-90.

Rottem, S. (1983). Characterization of membrane lipids. In Methods in Mycoplasmology, vol. 1, pp. 269-275. Edited by S. Razin \& J. G. Tully. New York: Academic Press.

Rottem, S. \& Markowitz, O. (1979). Membrane lipids of Mycoplasma gallisepticum: a disaturated phosphatidylcholine and a phosphatidylglycerol with an unusual positional distribution of fatty acids. Biochemistry 18, 2930-2935.

Ruschkowsky, S., Rosenshine, I. \& Finlay, B. B. (1992). Salmonella typhimurium induces an inositol phosphate flux in infected epithelial cells. FEMS Lett 95, 121-126.

Salman, M. \& Rottem, S. (1995). The cell membrane of Mycoplasma penetrans: lipid composition and phospholipase $A_{1}$ activity. Biochim Biophys Acta 1235, 369-377.

Shaw, J. H. \& Falkow, S. (1988). Model for invasion of human tissue culture cells by Neisseria gonorrhoeae. Infect Immun 56, 1625-1632.

Shibata, K.-I., Sasaki, T. \& Watanabe, T. (1995). AIDS-associated mycoplasmas possess phospholipase $\mathrm{C}$ in the membrane. Infect Immun 63, 4174-4177.

Wick, M. J., Madara, J. L., Fields, B. N. \& Normark, S. J. (1991). Molecular crosstalk between epithelial cells and pathogenic microorganisms. Cell 67, 651-659.

Received 13 January 1998; revised 22 May 1998; accepted 27 August 1998. 